\title{
PENERAPAN METODE PEMBELAJARAN GROUP INVESTIGATION (GI) UNTUK MENINGKATKAN KOMPETENSI INVESTIGASI KELOMPOK PADA SISWA KELAS XI IPS 1 SMA NEGERI 11 YOGYAKARTA
}

\author{
Sugiarti Merintika. L, Poerwanti Hadi Pratiwi dan Aris Martiana \\ Pendidikan Sosiologi FIS Universitas Negeri Yogyakarta \\ Email : sugiarti.merintika@student.uny.ac.id
}

\begin{abstract}
Abstrak
Penelitian ini dilatarbelakangi pembelajaran Sosiologi di SMA Negeri 11 Yogyakarta yang kurang variatif dalam menerapkan metode. Selain itu, penentuan metode kurang memperhatikan aspek tujuan pembelajaran, materi pelajaran, dan kondisi peserta didik. Penerapan metode GI ini didukung dengan penerapan media Google Classroom. Tujuan penelitian ini adalah untuk mengetahui bagaimana penerapan metode pembelajaran GI untuk meningkatkan kompetensi investigasi kelompok pada siswa kelas XI IPS 1.

Penelitian ini adalah jenis penelitian tindakan kelas (PTK) dalam dua siklus dengan alokasi waktu masing-masing tiga pertemuan pada setiap siklus. Subjek penelitian ini adalah 32 peserta didik kelas XI IPS 1 dan objek penelitian ini adalah kompetensi investigasi kelompok. Teknik pengumpulan data penelitian ini menggunakan observasi, angket, dan proyek. Analisis data penelitian ini menggunakan analisis kualitatif dan kuantitatif. Sumber data primer dalam penelitian ini adalah peserta didik dan guru, sementara sumber data sekunder adalah data administrasi sekolah. Validitas data dalam penelitian ini menggunakan validitas proses, yaitu mengetahui kesamaan data antara tiga instrumen.

Hasil penelitian ini menunjukkan peserta didik dapat mencapai kompetensi investigasi kelompok pada siklus I dan terjadi peningkatan pada siklus II. Hal ini dapat diketahui dari hasil observasi pembelajaran sesuai dengan sintaks dan peserta didik memenuhi indikator kompetensi investigasi kelompok. Selain itu, untuk hasil angket rata-rata kelas peserta didik siklus I sebesar $71 \%$ atau kategori B (baik) dan pada siklus II meningkat $13 \%$ menjadi sebesar $84 \%$ atau kategori A (sangat baik). Selain itu, sebagai data pendukung, hasil angket guru siklus I sebesar $79,16 \%$ atau kategori B (baik) dan meningkat $8,7 \%$ pada siklus II menjadi sebesar $92,70 \%$ atau kategori $A$ (sangat baik). Sementara itu, untuk hasil proyek rata-rata kelas peserta didik menunjukkan pada siklus I mencapai 83 dan meningkat pada siklus II menjadi 87. Kelebihan penelitian ini adalah kompetensi investigasi kelompok peserta didik meningkat dan memberikan pengalaman belajar bermakna. Sementara itu, kendala penelitian ini adalah keterbatasan waktu dan koneksi internet yang kurang stabil.

Kata kunci : Group Investigation, Google Classroom, kompetensi investigasi kelompok, pembelajaran Sosiologi.
\end{abstract}

\section{Abstract}

This research begin with a concern that the Sociology lesson in 11 Public High School Yogyakarta is less variative in applying the study method. Besides, the study method that has been chosen is not paying attention to study goal, material, and student's condition. The application GI method is also supported by the application of Google Classroom as a medium of study. This research aims to find out how the application of Gl study method will Increase Group Investigation Competence of the Grade XI Social Students.

This research type is a Class Action Research (CAR) that was implemented into two cycles consisting of three meetings for each cycle. The research subject was 32 students of 
Grade XI Social and the object of the study was group investigation competence. The data collecting was done by using observation, questionnaire, and project. The data was analyzed using both quantitative and qualitative data analysis. Primary data sources in this research are the students and the teachers while secondary data sources is the school administration data. The data is validated by using process validation that looks for similarity between three instruments.

The result of the study shows that the students can achieve group investigation competence in cycle I and shows further improvement in cycle II. This can be seen from the result of study observation according to the syntax and how the students fulfilling the indicators of group investigation competence. Moreover the average result of the students' questionnaire in cycle 1 is $71 \%$ or considered good, it increased to $13 \%$ to $84 \%$ or considered very good in cycle 2. The teachers questionnaire as supporting data resulted in $79,16 \%$ or considered good in cycle 1, increased further by $8,7 \%$ to 92,70 in cycle 2 that is considered very good. The average project result done by the students shows 83 in cycle 1 and 87 in cycle 2. This research strengths are on the students' increase of group investigation competence and give a meaningful learning experience to the students. The obstacles of this research are the time limitation and unstable internet connection.

Keywords: Group Investigation, Google Classroom, group investigation competence, Sociology learning.

\section{Pendahuluan}

Tujuan pendidikan terdiri dari umum dan khusus. Tujuan umum yakni tujuan Pendidikan nasional serta tujuan khusus yaitu tujuan instruksional (dicapai sekolah), tujuan kurikuler (dicapai mata pelajaran), dan tujuan instruksional (dicapai materi materi pelajaran). Tujuan pembelajaran merupakan bagian sekaligus penunjang tercapainya tujuan pendidikan sehingga harus dirumukan dengan baik dan dicapai secara optimal. Pencapaian tujuan pembelajaran memerlukan penerapan strategi pembelajaran dan metode pembelajaran yang tepat (Sanjaya,2013:125-127).

Berdasarkan hasil observasi oleh peneliti di SMA Negeri 11 Yogyakarta, guru sosiologi menerapkan strategi pembelajaran student center, yaitu pembelajaran yang berpusat pada peserta didik (Sanjaya,2013:125-127). Meskipun demikian, guru belum menerapkan metode pembelajaran secara variatif dan inovatif, yaitu sering menggunakan metode pembelajaran discovery. Hal tersebut menjadi

masalah pembelajaran kurang optimalnya pencapaian tujuan pembelajaran. Oleh karena itu, peneliti memilih SMA Negeri 11 Yogyakarta sebagai lokasi penelitian.

Penelitian di SMA Negeri 11 Yogyakarta merupakan penelitian tindakan kelas (PTK) model Kemmis dan Mc Taggart (Hopkins,2011:92) yang dilaksanakan di kelas XI IPS 1 tahun ajaran 2018/2019. Penentuan kelas XI

Penerapan Metode Pembelajaran Group Investigation (Gi) untuk Meningkatkan Kompetensi Investigasi Kelompok pada Siswa Kelas XI IPS 1 SMA Negeri 11 Yogyakarta 
IPS 1 sebagai objek penelitian berdasarkan masukan dari guru Sosiologi di sekolah karena memiliki karakteristik peserta didik yang heterogen sehingga memengaruhi proses pembelajaran menjadi kurang kondusif, kolaboratif, dan adanya ketimpangan. Sementara itu, sifat mata pelajaran Sosiologi abstrak dan materi riskan miskonsepsi (Kemendikbud, 2016:7).

Pada penelitian ini, materi yang diajarkan di kelas XI IPS 1 adalah Kompetensi Dasar (KD) 3.3. dan 3.4, yaitu konflik, kekerasan, serta perdamaian. Materi pelajaran tersebut menyesuaikan dengan kalender akademik sekolah dan program semester dengan alokasi waktu selama satu bulan, yaitu Januari 2019. Kajian materi konflik, kekerasan, dan perdamaian memerlukan kompetensi investigasi kelompok bagi peserta didik sebagai tujuan pembelajaran (Kemendikbud, 2016:18). Hal tersebut karena masih jarang dirumuskan sebagai tujuan pembelajaran dan akan menjadi temuan hasil penelitian menarik jika berhasil dicapai peserta didik kelas XI IPS 1. Selain itu, perumuskan tujuan pembelajaran kompetensi investigasi kelompok tersebut juga menjadi jawaban dari masalah pembelajaran di kelas, yaitu guru belum merumuskan tujuan pembelajaran secara tepat.

Demi mencapai kompetensi investigasi kelompok materi pelajaran konflik, kekerasan, dan perdamaian pada siswa kelas XI IPS 1, guru perlu menerapkan metode pembelajaran yang tepat (Pratiwi, 2014 : 83). Menurut Majid (2013) penerapan metode pembelajaran yang tepat adalah menyesuaikan dengan tujuan pembelajaran, materi pelajaran, dan karakteristik peserta didik. Oleh karena itu, peneliti menawarkan inovasi dan resolusi masalah pembelajaran melalui penerapan metode pembelajaran Group Investigation (GI). Penerapan metode pembelajaran Group Investigation (GI) dipilih karena fokus pada aktivitas investigasi kelompok yang dapat mencapai atau meningkatkan tujuan pembelajaran lebih optimal. Penelitian tindakan kelas ini bertujuan untuk mengetahui penerapan metode pembelajaran Group Investigation (GI) untuk meningkatkan kompetensi investigasi kelompok pada siswa kelas $\mathrm{XI}$ IPS 1 SMA Negeri 11 Yogyakarta.

\section{Metode}

Lokasi penelitian ini berada di SMA Negeri 11 Yogyakarta yang terletak di Jalan A.M Sangaji 50 Cokrodiningratan, Kecamatan Jetis, Kota Yogyakarta, 
Provinsi Daerah Istimewa Yogyakarta 55233. Waktu Penelitian ini dilaksanakan selama satu bulan, yaitu bulan Januari 2019. Subjek penelitian ini adalah peserta didik kelas XI IPS 1 SMA Negeri 11 Yogyakarta semester genap Tahun Ajaran 2018/2019. Objek penelitian ini adalah kompetensi investigasi kelompok pada siswa kelas XI IPS 1 SMA Negeri 11 Yogyakarta dalam pembelajaran Sosiologi materi konflik, kekerasan, dan perdamaian. Penelitian ini adalah jenis PTK model Kemmis dan Mc Taggart 1998 dalam Hopkins (2011:92). Penelitian ini dilakukan dalam dua siklus, masingmasing siklus tiga kali pertemuan yang melalui tahapan perencanaan (planning), pelaksanaan tindakan (action), obervasi (observation), dan refleksi (reflection).

Data dalam penelitian ini diambil dari teknik pengumpulan data observasi, angket, dan proyek. Sumber data dalam penelitian ini adalah data primer, yaitu peserta didik dan guru maupun data sekunder, yaitu data administrasi sekolah. Peserta didik merupakan sumber pengumpulan data untuk teknik observasi, proyek, dan angket. Sementara itu, guru merupakan sumber pengumpulan data angket.

Instrumen penelitian ini menggunakan observasi, angket, dan proyek. Pertama, observasi dilakukan pada saat proses pembelajaran penerapan metode pembelajaran GI untuk meningkatkan kompetensi investigasi kelompok peserta didik. Jenis observasi ini adalah partisipatif-kolaboratif oleh peneliti dan guru Sosiologi sebagai observer.

Kedua, angket yang diisi oleh responden, yaitu peserta didik kelas XI IPS 1 dan guru Sosiologi (Uno,2012:129). Instrumen angket diisi responden sesuai dengan kondisi sebenarnya pada saat proses pembelajaran. Instrumen angket yang digunakan dalam penelitian ini adalah jenis terstruktur skala tipe Likert untuk mengetahui skala jawaban dari masing-masing pernyataan dan konsistensi jawaban dari responden.

Ketiga, proyek Instrumen proyek digunakan untuk mengumpulkan data proses pembelajaran peserta didik yang berupa tugas. Instrumen proyek mengaju pada aturan penilaian dari sekolah dan panduan penilaian pembeajaran Kemendikbud (2015). Instrumen penelitian observasi, angket, dan proyek kemudian divalidasi menggunakan validitas proses yang berhubungan langsung dengan tindakan pembelajaran (Sanjaya,2015:41-42).

Teknik analisis data kualitatif untuk 
menganalisis instrumen observasi. Teknik analisis data kualitatif menggunakan milik Miles dan Huberman (2014), yaitu melalui tahap reduksi data, penyajian data, dan penyimpulan. Teknik analisis data kuantitatif untuk menganalisis instrumen angket dan proyek. Teknik analisis data angket menggunakan rumus dari Azwar (2018), yaitu :

Tabel 1. Rumus analisis data kuantitatif angket

\begin{tabular}{|l|l|}
\hline Skor $=\mathrm{R} \quad \mathrm{X} \quad \begin{array}{l}\text { Keterangan : } \\
\mathrm{R} \quad \text { skor yang } \\
\text { diperoleh } \\
\text { SM: skor maksimum } \\
\text { 100: bilangan tetap }\end{array}$ \\
\hline
\end{tabular}

Hasil penghitungan rumus di atas selanjutnya dikonversikan secara deskriptif dengan memperhatikan bobot pilihan, rentang skor, dan interval (Mertler,2011:261-267) :

Tabel. 2 Persentase kompetensi investigasi kelompok siswa kelas XI IPS 1 berdasarkan angket :

\begin{tabular}{|l|l|l|}
\hline Kategori & $\begin{array}{l}\text { Kriteria } \\
\text { Pencapaian }\end{array}$ & Predikat \\
\hline A & $81,25 \%-100 \%$ & Sangat Baik \\
\hline B & $62,50 \%-$ & Baik \\
& $81,25 \%$ & \\
\hline C & $43,75 \%-$ & Cukup \\
& $62,50 \%$ & \\
\hline D & $25 \%-43,75 \%$ & Kurang \\
\hline
\end{tabular}

Teknik analisis data proyek dianalisis dengan menentukan skor maksimum untuk tiap aspek yang dinilai adalah :

Rumus : Jumlah skor yang diperoleh

$$
\text { Jumlah skor maksimal. }
$$

${ }^{*}$ Kriteria penilaian menyesuaikan dengan sekolah, yaitu mencapai $75 \%$ (Kemendikbud,2015:26).

\section{Hasil dan Pembahasan}

\section{Deskripsi Lokasi Penelitian}

SMA Negeri 11 Yogyakarta terletak di Jalan A.M Sangaji nomor 50 Yogyakarta dan berdiri sejak tahun 1989.Gedung SMA Negeri 11 Yogyakarta merupakan peninggalan pada masa penjajahan Belanda, yaitu Hollands Inlandse Kweekschool (HIK) atau sekolah guru pada masa Belanda. Oleh karena itu, gedung sekolah SMA Negeri 11 Yogyakarta dilindungi pemerintah sebagai warisan cagar budaya. Visi SMA Negeri 11 Yogyakarta adalah terwujudnya sekolah yang unggul serta memiliki intelektualitas, integritas, santun, berwawasan kebangsaan dan bercakrawala global.

Kondisi fisik SMA Negeri 11 Yogyakarta terawat baik, dengan tanah seluas 11.344 meter persegi. Luas Gedung dan halaman SMA Negeri 11 Yogyakarta dikelilingi pagar sepanjang 
722 meter. Bangunan Gedung SMA Negeri 11 Yogyakarta terdiri dari ruangan maupun sarana dan prasarana dalam kondisi baik. Selain kondisi fisik SMA Negeri 11 Yogyakarta yang baik, kondisi non fisik juga baik. Notabene guru-guru SMA Negeri 11 Yogyakarta sudah bertatus PNS dan peserta didik memiliki potensi baik akademik maupun non akademik.

\section{Pelaksanaan Tindakan dan Hasil Penelitian}

a. Siklus I

PTK siklus I dilaksanakan dalam tiga kali pertemuan, yaitu dari hari Senin, 7 Januari 2019 sampai hari Senin, 14 Januari 2019. Pelaksanaan tindakan siklus I melalui tahapan perencanaan (planning), pelaksanaan (action), observasi (observation), dan refleksi (reflekction). Pada tahap perencanaan, peneliti melakukan penyusunan instrumen penelitian dan perangkat pembelajaran berupa RPP, modul, media pembelajaran, lembar observasi, angket, dan proyek. Pada tahap perencanaan, peneliti berkolaborasi dengan guru Sosiologi maupun rujukan kajian pustaka.

Pada tahap pelaksanaan, peneliti menerapkan metode pembelajaran Group Investigation (GI). Penerapan metode pembelajaran $\mathrm{Gl}$ dibantu dengan media pembelaran Google Classroom. Selain itu, peneliti menggunakan teknik pelaksanaan yang berbeda pada setiap pertemuannya. Pertemuan pertama dengan video animasi dan pembagian kelompok heterogen. Pertemuan kedua, topik investigasi dan lembar kerja. Pertemuan ketiga, artikel berita dan lembar kerja.

Setelah pelaksanaan tindakan, peneliti melakukan obervasi kolaboratif partisipatif bersama guru Sosiologi. Observasi dilakukan di setiap pertemuan dan dibantu dengan lembar observasi yang memuat indikator pengamatan. Hasil observasi menunjukkan peserta didik tindakan siklus I mencapai indikator investigasi kelompok dan sintaks metode pembelajaran $\mathrm{Gl}$ terlaksana dengan baik.

Observasi merupakan salah satu tahap dalam siklus PTK sekaligus teknik pengumpulan data. Selain observasi terdapat teknik pengumpulan data angket dan proyek. Teknik pengumpulan data angket digunakan untuk mengetahui penerapan metode pembelajaran GI serta keefektifannya untuk mencapai tujuan pembelajaran. Responden angket adalah peserta didik kelas XI IPS 1 dengan hasil rata-rata sebesar $71 \%$ atau kategori $B$ (baik) dan guru Sosiologi sebagai data pendukung dengan hasil $79,16 \%$ atau 
kategori B (baik). Sementara itu, capaian tujuan pembelajaran, yaitu kompetensi invetigasi kelompok diketahui dari hasil proyek dengan rata-rata kelas sebesar 83. Hasil proyek tersebut sudah memenuhi kriteria penilaian yang ditentukan.

Setelah observasi, tahap selanjutnya adalah refleksi, yaitu analisis data dan menyimpulkan. Pada tahap refleksi, peneliti melakukan bersama dengan guru Sosiologi dan dosen pembimbing. Hasil refleksi menunjukkan sintaks metode pembelajaran GI terlaksana, kompetensi investigasi kelompok peserta didik tercapai, dan proses pembelajaran berlangung baik. Meskipun demikian terdapat kendala, yaitu waktu terbatas, hasil angket yang belum mencapai kategori $A$ (sangat baik), beberapa peserta didik kurang kondusif dan kontributif, koneksi internet lambat, media presentasi belum variatif, serta peran peneliti masih dominan. Berdasarkan hasil refleksi siklus I tersebut peneliti melakukan upaya perbaikan melalui siklus II.

b. Siklus II

PTK siklus I dilaksanakan dalam tiga kali pertemuan, yaitu dari hari Kamis, 17 Januari 2019 sampai hari Kamis, 24 Januari 2019. Pelaksanaan tindakan siklus II melalui tahapan yang sama dengan siklus sebelumnya, mulai dari perencanaan (planning) hingga refleksi (reflekction). Pada tahap perencanaan, peneliti melakukan penyusunan instrumen penelitian dan perangkat pembelajaran berupa RPP, modul, media pembelajaran, lembar observasi, angket, dan proyek. Pada tahap perencanaan, peneliti berkolaborasi dengan guru Sosiologi maupun rujukan kajian pustaka.

Pada tahap pelaksanaan, peneliti menerapkan metode pembelajaran Group Investigation (GI) dan media pembelaran Google Classroom. Selain itu, peneliti menggunakan teknik pelaksanaan yang berbeda pada setiap pertemuannya. Pertemuan pertama dengan realitas konflik dan kekerasan, lembar kerja, serta peneliti mengatur posisi tempat duduk peserta didik menjadi bentuk tim. Pertemuan kedua, kuis pertanyaan dan diskusi, serta peneliti mengatur posisi tempat duduk bentuk tim. Pertemuan ketiga, teknik pelaksanaan video berita, lembar kerja, role playing talk show, serta peneliti mengatur posisi tempat duduk bentuk ruang kerja.

Setelah pelaksanaan tindakan, peneliti melakukan obervasi kolaboratifpartisipatif bersama guru Sosiologi. Observasi dilakukan di setiap pertemuan dan dibantu dengan lembar observasi. 
Hasil observasi menunjukkan kompetensi investigasi kelompok peserta didik di siklus II meningkat, sintaks metode pembelajaran $\mathrm{GI}$ terlaksana dengan baik, peserta didik kondusif, kooperatif, dan kontribustif dalam proses pembelajaran.

Observasi selain merupakan salah satu tahap dalam siklus PTK juga sekaligus teknik pengumpulan data. Berdasarkan hasil teknik pengumpulan data yang lain, yaitu angket dengan responden peserta didik kelas XI IPS 1 menunjukkan hasil rata-rata sebesar $84 \%$ atau kategori $A$ (sangat baik) dan guru Sosiologi sebagai data pendukung dengan hasil $92,70 \%$ atau kategori $A$ (sangat baik). Sementara itu, capaian tujuan pembelajaran, yaitu kompetensi invetigasi kelompok diketahui dari hasil proyek yang meningkat dengan rata-rata kelas sebesar 87 atau tuntas.

Setelah observasi, tahap selanjutnya adalah refleksi, yaitu analisis data dan menyimpulkan. Pada tahap refleksi, peneliti melakukan bersama dengan guru Sosiologi dan dosen pembimbing. Hasil refleksi menunjukkan sintaks metode pembelajaran GI terlaksana, kompetensi investigasi kelompok peserta didik meningkat, proses pembelajaran berlangung baik dan tepat waktu, peserta didik kondusif, kolaboratif, maupun kooperatif, koneksi internet cepat, hasil angket responden mencapai kategori A (sangat baik), serta hasil proyek peserta didik meningkat. Berdasarkan refleksi tersebut yang menunjukkan kelebihan dan tidak ada kendala maka tindakan selesai di siklus II.

\section{Pembahasan}

a. Penerapan metode pembelajaran GI di kelas XI IPS 1. Penerapan metode pembelajaran $\mathrm{Gl}$ dibantu dengan media pembelajaran Google Classroom yang berfungsi sebagai sumber dan media menyampaikan materi. Menurut Soni (2018) media pembelajaran Google Classroom memiliki kelebihan memudahkan guru dalam membuat, membagikan, mengelompokkan tugas maupun materi secara paperless, namun untuk mengaksesnya diperlukan koneksi internet. Selain itu, media pembelajaran Google Classroom juga dapat digabungkan dengan pembelajaran konvensional dalam hal ini penerapan metode $\mathrm{GI}$ di kelas.

b. Penerapan metode pembelajaran GI dapat diketahui dari hasil observasi, yaitu pada pertemuan pertama siklus I peneliti membuka kegiatan pembelajaran dan peserta didik kooperatif. Peneliti membagi peserta 
didik menjadi lima kelompok kecil karena memperhatikan aspek variasi individual peserta didik (Santrock, 2014:124) dan menurut Slavin (2016) komunikasi maupun interaksi kooperatif akan mencapai hasil terbaik. Selain itu, menurut Wardianto (2017) juga dapat meningkatkan produktivitas. Setelah kelompok belajar dibentuk, peserta didik duduk bersama kelompoknya dan peneliti menyampaikan instruksi, namun peserta didik kurang memperhatikan sehingga peneliti menayangkan video animasi kemudian meminta peserta didik mengkaitkannya dengan materi yang akan dipelajari. Video animasi merupakan bagian dari video pembelajaran yang membantu dalam sumber maupun memahami materi (Hendrastomo, 2018:29). Video pembelajaran merupakan salah satu media pembelajaran efektif dan sesuai dengan kebutuhan pembelajar khususnya anak generasi $Z$ yang lahir antara tahun 1995-2009 (Luhulima, 2016:85-91).

Video yang ditayangkan kemudian ditonton melalui Google Classroom dan diidentifikasi peserta didik. Peserta didik sudah familier menggunakan media pembelajaran Google Classroom, namun belum untuk metode pembelajaran GI sehingga peneliti memberikan instruksi setiap pergantian sintaks. Setelah sintaks identifikasi topik, peserta didik kemudian investigasi kelompok, menyusun laporan dan presentasi. Pada saat presentasi, media yang dibuat belum variatif (semua menggunakan power point). Secara keseluruhan pertemuan I berlangsung baik namun terkendala koneksi internet dan peran peneliti yang masih dominan karena kondisi peserta didik di kelas.

Adanya kendala pada pertemuan pertama siklus I mendorong peneliti untuk melakukan pengelolaan kelas yang menurut hasil riset Minsih (2008) dapat menciptakan dan mempertahankan kondisi kelas agar kegiatan pembelajaran berlangsung efektif dan efisien. Pengelolaan kelas ini dilakukan peneliti mulai pertemuan kedua siklus I sampai seterusnya.

Pada pertemuan kedua siklus I, peneliti membuat undian pilihan topik investgasi untuk setiap kelompok guna menghindari efek free rider, yaitu pengerjaan tugas yang tidak merata bagi setiap anggota kelompok. Menurut Aliman (2018) yang mengalami kendala sama mengupayakan penanggulangan dengan pembagian tugas merata dan adanya pengawasan oleh guru. Pilihan topik 
investigasi dapat peserta didik unduh melalui Google Classroom, namun mengalami kendala koneksi internet belum stabil sehingga peneliti menambatkan koneksi internet dari handphone pribadinya sehingga proses pembelajaran menjadi lancar sampai ke sintaks presentasi. Pada sintaks presentasi, peserta didik sudah membuat media presentasi menarik dan variatif.

\section{Pertemuan}

pembelajaran

selanjutnya, yaitu pertemuan ketiga siklus I dilaksanakan hari Senin sehingga peneliti dan peserta didik sepakat untuk istirahat setelah pembelajaran Sosiologi selesai. Hal ini karena pada hari Senin pekan lalu pembelajaran mengalami kendala karena terpotong jam istirahat yang berakibat suasana kelas kurang kondusif. Pada pertemuan ketiga siklus II, peneliti mengajak peserta didik untuk menginvestigasi topik artikel berita yang berbeda untuk setiap kelompok. Artikel berita dipilih karena menurut Wulandari (2013) dapat membantu peserta didik memperoleh sumber belajar yang efektif.

Investigasi artikel berita oleh peserta didik diatas mengalami kendala koneksi internet kurang stabil, kemudian peneliti mengajak untuk belajar di perpustakaan. Ketika di perpustakaan, pembelajaran mengalami kendala peserta didik bingung memilih sumber referensi yang relevan dan LCD proyektor sedang digunakan oleh kelas lain. Kondisi demikian diselesaikan guru dengan memberikan lembar print out pembelajaran namun disisi lain pembelajaran menjadi tidak paperless.

Berdasarkan hasil observasi di atas penerapan metode pembelajaran $\mathrm{Gl}$ di kelas XI IPS 1 pada siklus I kurang berjalan lancar. Sementara itu, untuk hasil angket rata-rata kelas dengan 32 responden peserta didik sebesar $71 \%$ atau kategori $B$ (baik) dan untuk hasil data pedukung oleh responden guru sebesar $79,16 \%$ atau kategori B (baik). Kekurangan pada siklus I ini selanjutnya diperbaiki oleh peneliti melalui siklus II.

Penerapan metode pembelajaran GI di kelas XI IPS 1 pada siklus II dilakukan optimalisasi. Berdasarkan hasil observasi pertemuan pertama siklus II karena peserta didik masih kurang kondusif maka peneliti mengatur tempat duduk bentuk tim, yaitu pengelompokkan meja dalam kelas secara melingkar atau setengah lingkaran. Menurut Siberman (2014) posisi tempat duduk bentuk tim mampu meningkatkan interaksi antar anggota tim.

Selain mengatur posisi tempat duduk bentuk tim, pada pertemuan kedua 
siklus II peneliti menerapkan pembelajaran kontekstual konflik, kekerasan, dan perdamaian di lingkungan sekitar peserta didik. Pembelajaran kontekstual bermanfaat membantu peneliti maupun peserta didik mengkaitkan materi pelajaran dengan dunia nyata dan memotivasi untuk membuat hubungan antara pengetahuan dengan penerapan (US Departement of Education the National School to Work Office dalam al Tabany, 2014:138-139).

Pada pertemuan pertama siklus II pembelajaran tidak mengalami kendala baik dari sintaks identifikasi topik hingga presentasi dengan media presentasi sudah variatif. Hal ini karena koneksi internet lancar. Setelah pertemuan pertama siklus II, peneliti melaksanakan pertemuan kedua siklus II di hari Senin sehingga istirahat dilakukan setelah pembelajaran selesai. Pertemuan kedua siklus II ini, peneliti melaksanakan teknik pelaksanaan kuis interaktif yang menurut hasil riset Purwadi (2009) dapat berpengaruh terhadap tujuan pembelajaran serta percaya diri peserta didik. Pelaksanaan pertemuan kedua siklus II berlangsung baik, lancar dan sesuai harapan sehingga dilanjutkan dengan pertemuan ketiga siklus II.

Pada pertemuan ketiga siklus II, peneliti menggunakan teknik pelaksanaan identifikasi video berita konflik, kekerasan dan perdamaian serta role playing talk show ketika presentasi. Teknik pelaksanaan tersebut didukung juga dengan mengatur posisi tempat duduk bentuk ruang kerja, yaitu menurut Silberman (2014) menempatkan peserta didik anggota kelompok di meja yang sama. Posisi tempat duduk ini baik untuk mendorong kemitraan dalam belajar dan menujang investigasi kelompok (Joyce, 2011: 299).

Penerapan teknik pelaksanaan di pertemuan ketiga siklus II dipilih karena video berita dapat memberikan pengalaman belajar secara nyata bagi peserta didik. Menurut Dale dalam Sanjaya (2015) pengalaman belajar secara nyata tersebut terdapat pada tingkat konkret kerucut pengalaman yang memiliki tingkat keberhasilan sebesar $70 \%$. Video artikel berita tersebut diidentifikasi kemudian diinvestigasi oleh peserta didik. Setelah investigasi kelompok, peserta didik menyusun laporan dan dipresentasikan dengan role playing talk show. Role playing talk show menurut hasil riset Jiyanto (2015) memiiki kelebihan dapat meningkatkan kreativitas peserta didik dan meningkatkan kompetensi public speaking peserta didik. 
Berdasarkan hasil observasi diatas menunjukkan proses pembelajaran berlangsung lancar. Selain itu, untuk mengetahui penerapan metode pembelajaran GI di kelas XI IPS 1 secara objektif. Peneliti membagikan angket kepada responden, yaitu peserta didik dan guru Sosiologi menunjukkan rata-rata sebesar $84 \%$ atau kategori baik $A$ (sangat baik). Hasil angket peserta didik tersebut didukung juga dengan data angket dari guru sebesar $92,70 \%$ atau kategori $A$ (sangat baik). Jadi, dapat disimpulkan bahwa penerapan metode pembelajaran GI di kelas XI IPS 1 menunjukkan kesesuaian atau terlaksana.

\section{Penerapan metode pembelajaran GI} untuk meningkatkan kompetensi investigasi kelompok pada siswa kelas XI IPS 1.

Metode pembelajaran GI merupakan salah satu dari variasi metode pembelajaran kooperatif (Slavin, 2016: 214). Penerapan metode pembelajaran GI dilakukan karena menyesuaikan dengan materi pembelajaran, kondisi peserta didik, dan tujuan pembelajaran (Majid, 2013: 136-137). Materi pembelajaran Sosiologi yang dikaji adalah konflik, kekerasan, dan perdamaian. Materi tersebut riskan miskonsepsi pada kajiannya, sementara itu kondisi peserta didik kelas XI IPS 1 bersifat heterogen sehingga dirumuskan tujuan pembelajarannya adalah kompetensi investigasi kelompok (Kemendikbud,2016: 18).

Penerapan metode pembelajaran GI ditunjang juga dengan penerapan media pembelajaran Google Classroom. Media pembelajaran Google Classroom tersebut sudah familier bagi peserta didik dan membantu mereka untuk beradaptasi dengan penerapan metode $\mathrm{Gl}$ untuk meningkatkan kompetensi investigasi kelompok. Peningkatan kompetensi investigasi kelompok tersebut dapat diketahui dari indikator capaian yang dalam penelitian ini menggunakan rujukan dari Moeed (2013) untuk menjawab keterbatasan metode pembelajaran GI milik Slavin (2016). Metode pembelajaran GI milik Slavin hanya membahas pada dasar pemikiran dan implementasi, sementara Moeed (2013) membahas tentang penerapan dan kompetensi investigasi kelompok. Kompetensi investigasi kelompok yang dikemukakan oleh Moeed (2013) meliputi mengumpulkan data, memproses data, merumuskan hipotesis, dan resolusi.

Pencapaian kompetensi investigasi kelompok peserta didik kelas XI IPS 1 
diketahui dari hasil pengumpulan data di lapangan. Berdasarkan hasil observasi siklus I dan II, penerapan metode pembelajaran $\mathrm{Gl}$ berhasil mencapai dan meningkatkan kompetensi investigasi kelompok.

Hasil observasi di atas didukung juga oleh hasil angket peserta didik dan guru Sosiologi. Angket diisi responden sesuai dengan kondisi sebenarnya pada saat proses pembelajaran. Berdasarkan hasil angket peserta didik menunjukkan penerapan metode pembelajaran GI dapat mencapai kompetensi investigasi kelompok siswa kelas XI IPS 1 pada siklus I, yaitu dengan rata-rata kelas sebesar $71 \%$ atau kategori B (baik) dan hasil angket guru sebesar $79,16 \%$ atau kategori B (baik). Sementara itu hasil angket peserta didik pada siklus II mengalami peningkatan yaitu rata-rata kelas sebesar $84 \%$ atau kategori $A$ (sangat baik). Hasil angket peserta didik tersebut didukung juga oleh hasil angket guru sebesar $92,70 \%$ atau kategori $A$ (sangat baik). Jadi hasil angket dari siklus I ke siklus II meningkat sebesar $13 \%$ untuk peserta didik dan sebesar $8,7 \%$ untuk guru.

Penerapan metode pembelajaran GI untuk meningkatkan kompetensi investigasi kelompok pada siswa kelas XI
IPS 1 diketahui juga melalui hasil penilaian proyek. Berdasarkan hasil penilaian proyek peserta didik pada siklus I mencapai nilai rata-rata secara klasikal baik dan melebihi KKM (Kriteria Ketuntasan Minimal), yaitu 83 dari nilai maksimal 100 , sementara pada siklus II mencapai 87. Berdasarkan perolehan hasil penilaian proyek peserta didik pada siklus I ke siklus II mengalami peningkatan sebesar 4 .

Jadi dapat disimpulkan bahwa penerapan metode pembelajaran GI dapat meningkatkan kompetensi investigasi kelompok pada siswa kelas XI IPS 1.

\section{Kendala Penerapan Metode Pembelajaran GI untuk Meningkatkan Kompetensi Investigasi Kelompok pada Siswa Kelas XI IPS 1.}

Penerapan metode pembelajaran GI untuk meningkatkan kompetensi investigasi kelompok pada siswa kelas XI IPS 1 dilaksanakan pada mata pelajaran Sosiologi materi konflik, kekerasan dan perdamaian. Penerapan metode pembelajaran GI dilaksanakan dalam dua siklus tindakan masing-masing tiga kali pertemuan dengan hasil siklus I mencapai kompetensi investigasi kelompok dan 
terjadi peningkatan di siklus II. Hasil tersebut dapat diketahui dari indikator investigasi kelompok pada instrumen penelitian observasi, angket, maupun proyek. Penerapan metode pembelajaran GI untuk meningkatkan kompetensi investigasi kelompok pada siswa kelas XI IPS 1 berhasil karena melalui perbaikan dari kendala proses pembelajaran yang upaya-upayanya sudah peneliti jelaskan di subbab pembahasan sebelumnya. Kendala proses pembelajaran yang dihadapi peneliti meliputi faktor internal maupun eksternal.

Kendala faktor internal penerapan metode pembelajaran $\mathrm{Gl}$ merupakan kendala yang disebabkan oleh peserta didik kelas XI IPS 1, yaitu pertama beberapa peserta didik ada yang kurang kontributif dalam tugas kelompok dan menyebabkan suasana kelas kurang kondusif. Kedua, meskipun peserta didik sudah di bagi ke dalam kelompok kecil heterogen, namun masih belum dapat melakukan pembagian tugas dengan baik. Ketiga, peserta didik kesulitan menginvestigasi topik dari artikel berita karena kurang dekat dengan kehidupan sehari-hari. Keempat, peserta didik lupa mengecek notifikasi Google Classroom dan mencantumkan sumber referensi valid di lembar kerja. Kelima, media presentasi yang dibuat peserta didik masih belum variatif. Keenam, beberapa peserta didik ada yang kurang memperhatikan instruksi peneliti. Ketujuh, peserta didik masih belum familier menerapkan metode pembelajaran $\mathrm{GI}$.

Kendala faktor eksternal penerapan metode pembelajaran GI merupakan kendala yang disebabkan oleh aspek luar selain peserta didik kelas XI IPS 1, yaitu pertama alokasi waktu yang terbatas selama satu bulan sehingga peneliti harus dapat mengoptimalisasi penerapan metode GI untuk meningkatkan kompetensi investigasi kelompok. Kedua, koneksi internet kurang stabil sehingga peserta didik mengerjakan tugas investigasi di perpustakaan dan pembelajaran tidak sepenuhnya paperless. Ketiga, ketika di perpustakaan LCD proyektor sedang dipakai sehingga peserta didik terkendala untuk presentasi.

Keempat, peran peneliti masih dominan dalam pembelajaran. Kelima, jam pembelajaran Sosiologi hari Senin berada di antara jam istirahat dan pada hari Kamis setelah istirahat siang. Keenam, kendala proses pembelajaran yang dihadapi adalah pelajaran Sosiologi bersifat abstrak dan materi konflik, kekerasan, serta perdamaian riskan miskonsepsi. 


\section{Simpulan}

Penelitian penerapan metode pembelajaran $\mathrm{Gl}$ dan media pembelajaran Google Classroom ini dilaksanakan di kelas XI IPS 1 SMA Negeri 11 Yogyakarta tahun ajaran 2018/ 2019. Penelitian tindakan ini dilaksanakan bulan Januari 2019 selama dua siklus. Pada pelaksanaannya peneliti berkolaborasi dengan guru Sosiologi. Pengumpulan data pada penelitian ini menggunakan teknik observasi, angket, dan proyek. Berdasarkan pelaksanaan hasil penelitian tindakan menunjukkan terjadi peningkatan kompetensi investigasi kelompok pada siklus II. Hasil penelitian tindakan ini diketahui dari instrumen penelitian, yaitu observasi, angket maupun proyek. Berdasarkan hasil observasi (data kualitatif) menunjukkan siklus I mencapai kompetensi investigasi kelompok dan meningkat pada siklus II. Berdasarkan hasil angket (data kuantitatif) menunjukkan rata-rata kelas peserta didik pada siklus I sebesar $71 \%$ atau kategori $B$ (baik) dan pada siklus II meningkat 13\% menjadi sebesar $84 \%$ atau kategori $A$ (sangat baik). Selain itu, sebagai data pendukung, hasil angket guru sebesar $79,16 \%$ atau kategori B (baik) dan meningkat $8,7 \%$ menjadi sebesar $92,70 \%$ atau kategori $\mathrm{A}$ (sangat baik). Sementara itu, untuk hasil proyek (data kuantitatif) menunjukkan rata-rata kelas peserta didik menunjukkan pada siklus I mencapai 83 dan meningkat pada siklus II menjadi 87. Jadi dapat disimpulkan hasil penelitian tindakan penerapan metode pembelajaran $\mathrm{Gl}$ dapat meningkatkan kompetensi investigasi kelompok peserta didik kelas XI IPS 1. Berdasarkan hasil penelitian penerapan metode pembelajaran GI maka peneliti merekomendasikan tindakan ini diterapkan guru Sosiologi di sekolah guna meningkatkan maupun memperbaiki kualitas pembelajaran.

Penerapan metode pembelajaran GI memiliki kelebihan dapat membantu guru Sosiologi di sekolah sebagai salah satu pilihan inovasi pelaksanaan pembelajaran maupun solusi masalah pembelajaran di kelas karena memperhatikan aspek tujuan pembelajaran, materi dan karakteristik peserta didik. Kelebihan lainnya adalah peserta didik dapat memperoleh hikmah pembelajaran (lesson learned) dan dapat mengetahui seluruh proses pembelajaran untuk meningkatkan kompetensi investigasi kelompok. Selain itu, untuk menghadirkan realitas sosial kepada peserta didik maka dalam penerapan 
metode pembelajaran $\mathrm{Gl}$ dibantu dengan penerapan media Google Classroom. Keterbatasan penelitian tindakan ini adalah Keterbatasan waktu yaitu selama satu bulan penelitian. Penelitian ini fokus pada proses pembelajaran sehingga diperlukan tambahan penilaian tes untuk fokus pada proses hasil pembelajaran. Penerapan media pembelajaran Google Classroom bergantung pada koneksi internet yang kemudian berdampak pada pembelajaran belum sepenuhnya paperless jika koneksi internet kurang stabil, Penelitian ini hanya dapat dilakukan dalam kelompok kecil dan harus didukung dengan teknik pembagian kelompok serta penempatan posisi tempat duduk yang sesuai.

Keberhasilan penelitian berupa kompetensi investigasi kelompok yang meningkat bukan berarti terjadi juga pada mata pelajaran selain Sosiologi dan semua kelas di SMA Negeri 11 Yogyakarta. Penerapan metode pembelajaran GI dan media pembelajaran Google Classroom belum tentu dapat diterapkan di semua mata pelajaran dan semua kelas. Perlu analisis kebutuhan dan masalah pembelajaran terlebih dahulu. Meskipun demikian, metode pembelajaran GI dan media pembelajaran Google Classroom dapat menjadi rekomendasi inovasi dan resolusi proses pembelajaran untuk diterapkan.

\section{Ucapan Terimakasih}

Terimakasih disampaikan kepada semua pihak yang terlibat dalam penelitian ini sehingga terlaksana dengan baik dan tim redaksi Jurnal Pendidikan Sosiologi Fakultas IImu Sosial UNY yang telah mempublikasikan penelitian ini

\section{Daftar Pustaka}

A, Craig Mertler. (2011). Action Research. Yogyakarta : Pustaka Pelajar.

Aliman.(2016). "Model Pembelajaran Group Investigation Berbasis Spasial Thinking', paper di presentasikan di Seminar Nasional Geografi "Kecerdasan Spasial dalam Pembelajaran dan Perencanaan Pembangunan di RSG FT UNP, 19 November 2016.
Al-Tabany,Trianto.(2014).Mendesain Model Pembelajaran Inovatif,Progresif, dan Kontekstual.Jakarta:Kencana.

Azwar, Saifuddin. (2018). Metode Penelitian Psikologi. Yogyakarta : Pustaka Pelajar.

B, Hamzah Uno. (2012). Assessment Pembelajaran. Jakarta : Bumi Aksara.

B, Matthew Miles dan Huberman. (2014). Analisis Data Kualitatif. Jakarta : 
UI Press.

E, Robert Slavin. (2016). Cooperative Learning : Teori, Riset, dan Praktik. Bandung : Nusa Media.

E, Sharon Smaldino. (2014). Instructional Technology and Media for Learning. Jakarta : Kencana.

Hadi, Poerwanti Pratiwi. (2014). Perencanaan Pembelajaran Sosiologi. Yogyakarta :UNY Press.

Hendrastomo,Grendi dan Nur Endah. (2018). Inovasi Pembelajaran Sosiologi Kurikulum 2013 melalui Pengembangan Media Pembelajaran Berbasis Teknologi Informasi.Jurnal Pendidikan, Sosiologi, dan Antropologi.2(1):72-91.

Hopkins, David. (2011). A Teacher's Guide To Classroom Research. Yogyakarta.Pustaka Pelajar.

Jiyanto.(2015).Implementasi Pembelajaran Kooperatif Model Talkshow Pada Pembelajaran PPKn di SMA Negeri 2 Pacitan.Jurnal Humaniora.2(3):23-27.

Joyce,Bruce.dkk. (2011). Models of Teaching.Yogyakarta:Pustaka Pelajar.

Kemendikbud. (2015). Panduan Penilaian Untuk SMA. Jakarta : Kemendikbud.

(2016). Silabus Mata Pelajaran Sosiologi SMA/MA. Jakarta:Kemendikbud.
L, Melvin Silberman. (2014). Active Learning: 101 Cara Belajar Siswa Aktif. Bandung : Nuansa Cendekia.

Luhulima.(2016).Pembelajaran Berbasis Video untuk Anak Generasi Z.Prosiding Inovasi Pendidikan di Era Big Data dan Aspek Psikologisnya Prodi Teknologi Pembelajaran dan Psikologi Pendidikan Pascasarjana Universitas Negeri Malang,Malang:31 November 2016. Hal.85-92.

Majid, Abdul. (2013). Perencanaan Pembelajaran : Mengembangkan Standar Kompetensi Guru. Bandung : Rosda.

Minsih dan Aninda Galih.(2018).Peran Guru dalam Mengelola Kelas.Jurnal Profesi Pendidikan Dasar.5(1):20-27.

Moeed, Azra. (2013). Science Investigation That Best Supports Students Learning : Teachers' Understanding of Science Investigation. International Journal of Environmental and Science Education : 537-559.

Peraturan Pemerintah nomor 19 tahun 2005 tentang Standar Pendidikan Nasional.

Purwadi.(2009).Pengaruh Metode Kuis Interaktif Terhadap Prestasi Belajar Matematika Ditinjau dari Sikap Percaya Diri. Tesis S2.Tidak Diterbitkan.Universitas Sebelas Maret Surakarta.

Sanjaya.(2013). Strategi Pembelajaran : Berorientasi Standar Proses Pendidikan. Jakarta:Kencana. 
Wina. (2015). Perencanaan dan Desain Sistem Pembelajaran. Jakarta : Kencana.

Wina. (2015). Penelitian Tindakan Kelas. Jakarta : Kencana.

Soni.dkk. (2018). Optimalisasi Pemanfaatan Google Classroom sebagai Media Pembelajaran di SMK Negeri 1 Bangkinang. Jurnal Pengabdian untuk $\mathrm{Mu}$ NegeRI. 2 (1) :17-20.

Undang-undang nomor 20 tahun 2003 tentang Sistem Pendidikan Nasional.

Wardianto. (2017). Perancangan Sistem Pembagian Kelompok Belajar Berbasis Nilai dan Personality
Traits menggunakan Agloritma Klusterisasi Partitioning Around Medoids (PAM) dan Distribusi Kemampuan Merata. Skripsi S1. Tidak Diterbitkan. Universitas Islam Sultan Agung Semarang.

W, John Santrock. (2013). Psikologi Pendidikan. Jakarta : Kencana.

Wulandari,Rika.(2013).Pemanfaatan Media Berita Peristiwa dalam Surat kabar pada Pembelajaran Menulis Naskah Drama, Laporan Hasil Penelitian Eksperimen pada Siswa Kelas XI MAN 1 Bandung Tahun Ajaran 2012/2013,Jurusan Pendidikan Bahasa dan Sastra Indonesia FPBS Universitas Pendidikan Indonesia. 